\title{
Anthropological Studies of Mobile Phones
}

\section{Daniel Miller}

\section{Julie Soleil Archambault 2017 Mobile Secrets: Youth, Intimacy, and the Politics of Pretense in Mozambique. Chicago: University of Chicago Press}

\author{
Foster Robert and Horst, Heather. Eds. 2018 The Moral Economy of Mobile \\ Phones: Pacific Islands Perspectives. Australian National University Press
}

Tenhunen, Sirpa 2018 A village Goes Mobile: Telephony, Mediation, and Social Change in Rural India. Oxford University Press

As far as I am aware The Cell Phone (Horst and Miller 2005) was the first attempt at an ethnography of the mobile phone. Our funding came from UK aid and this meant we had quite specific concerns with the impact of the phone upon poverty. One result of this was that we emphasised the way people expanded their social connections. Many Jamaicans without any income tried to find ways to 'link-up' with Jamaicans who had some kind of income in order just to get by. This was in contrast with much of the more general writing of the time, that showed how phones connections tended to replicate the tight network of close friends and relatives (Ling 2004).

What makes an approach anthropological is partly how one draws conclusions from this difference. Most journalists and social scientists seek to understand a technology in terms of generalisation. What difference have mobile phones made, what do people do with them? But we didn't see our findings in Jamaica as a test for a hypothesis about the social connections of the mobile phone. We simply assumed that you would find a wide range of appropriations of the phone depending upon the local cultural context. This approach is also reflected in my own recent project summarised in How The World Changed Social Media (Miller et all 2016).

This has consequences. Generalised observations lend themselves to explanations that invoke technology as causation. The reason for the social change may derive from the properties of the device or platform. In order to avoid a simple technological determinism the most popular language today is that of 'affordances' (Costa 2018) which acknowledge properties and propensities in the technology but subject to modification in actual usage. Our project on social media was more radical in its focus upon cultural relativism. We showed how the same genre of activity, such as playground banter or the meme, quite happily migrated from Blackberry phones, to Orkut or Facebook or Twitter. If the genre of usage remained largely the same across these very different platforms then the properties or affordances of the platforms were largely irrelevant to explaining their usage.

This review provides an opportunity to consider how anthropologists have extended their reach in the fifteen years following that initial ethnography. The most obvious point of departure is the book by Tenhunen. Because the key contribution is precisely one of longevity. The volume is based on the continuous study of a village of around 2,400 inhabitants in West Bengal between 1999 and 2013. Reference is made to theoretical frames such as domestication, remediation and polymedia, but 
the real strength is simply empirical; the depth and breadth of observation. The anthropologist is not trying to present a typical Indian village. She knows that India is too diverse for that, rather it is to understand a specific Indian village. This kind of time scale helps avoid much hype and exaggeration; especially the dualism we tend to read, as in opposing screens $v$ face-to-face. Instead Tenhunen situates the phone amongst a wide variety of forms of co-presence. At first it is very local issues that matter. Amongst the first usage is being able to tell people about a death so they could attend funerary rituals. Gradually, however, the phone takes its place alongside the more general changes during this period in which people become aware of and able to interact with a wider landscape whether political, social or economic.

As in the Why We Post project the emphasis is often, less on radical change, than on more conservative uses of the phone which tried to repair the problems caused by other shifts within modern life. The key to understanding phone usage remains kinship, for example, telling ones relatives about work opportunities, or organising healthcare. Gradually more radical changes occur especially for women, as wives can now stay in touch with natal families when they leave home to marry. But the emancipatory impact is limited. Generally phones are not individually owned and women may depend on husbands or in-laws in order to make calls. An important development concerns lower castes who hadn't been able to afford a television but leapfrog other technologies to obtain cheap smartphones and may gain access to factory work. As recently noted in The Economist (08/06/2019) the primary driver behind much of the uptake are not fields such as politics or the economy, but rather the range of entertainment and fun that people can access through these new phones.

But the basic hierarchy and caste system remains, and because of differences in literacy new digital divides develop in respect to the ability to make use of the capacities represented by these phones. But phones do give entry to a wider landscape, for example, of alternative political possibilities, as well as simply greater spends of communication. Generally the conclusions are similar to those of Venkatraman (2017) working on the impact of social media at the other end of India near Chennai. Both focus upon traditional structures such as kinship, gender and caste. Both try to show the contradictions and nuances with respect to change in these domains, balancing the conservative uses with the possibilities of emancipation.

The tendency of anthropologists to eschew the general debates about the impact of the phone and instead delve more deeply into highly specific local issues is even more pronounced in the book by Archambault. Again we are working in a situation of poverty and struggle, set in the suburb of a provincial town in Mozambique. This is a million miles from the debates about how phones are taking away our privacy that dominate debates in the UK or the US. The main emphasis in this book is the capacity of the phone for subterfuge and secrecy. As with Tenhunen, you are constantly made aware of the other social changes that are the context to the appropriation of the mobile phone, in this case new forms of intimacy. 
People see the phone as a way of concealing certain things, while making others apparent. How for example to display social status without attracting envy. If you want to arrange meetings with a lover, the phone seems to make it much easier to make all the requisite arrangements in secret. But then phones also provide new ways to check up on people, in which case it is the phone that is blamed for the exposure, not the infidelity itself. This is a place where respectability depends not upon what you do, but your ability to be discrete about it. In a situation of precarity, turning a blind eye may be essential to economic survival. Phones are also easy to steal, easy to sell, and create their own underground economy based on crime. This book is therefore extremely valuable in appreciating the very limited discussions and the parochialism of our usual debates. In another part of the world the presence of the mobile phone raise all sorts of other questions about trust and intimacy that dominate local conversation about what a mobile phone actually is.

These books by Tenhunen and Archambault illustrate the capacity of anthropologists to change our perspective and start to appreciate what it must be like to be a villager in India or a young man in urban Africa with a new mobile phone. It is very hard to extrapolate general technological cause or even the weaker argument around affordances, when faced with these radical differences in context and forms of appropriation and use. But this by no means exhausts the potential of anthropology. The edited collection by Foster and Horst is a much broader based exploration of the context and impact of the mobile phone.

While Tenhunen shows the advantage of following one community through an extended study, Horst is able to follow one company over a comparable period, since the main supplier of mobile phones to the Pacific in 2017 is Digicel, the same company that we studied in Jamaica in 2005, Having cut its teeth in bringing mobile phones to small island populations in the Caribbean, starting with Jamaica in 2001, Digital then transferred this expertise to the Pacific, starting with Samoa in 2006, and reaching at one point $97 \%$ of market share in Papua New Guinea. These are the kind of areas where you need helicopters, followed by a long hike, to set up a phone mast.

Again there are a range of particular local contextual factors. The chapter by Lipset shows how people see the phone as a liberation from the constraints of traditional kinship, since this may be, in effect, the first time one can contact strangers. A poignant example of this comes in the chapter by Wardlow who worked with women infected by HIV. They may find themselves shunned by their kin, but through using random calling they can find supportive strangers who give them emotional and practical care and don't ask for money, sex or pigs in return, unlike family and boyfriends. There are echoes of Tenhunen in the way women use phones to remain in contact with natal households, and with Archambault in how young men in towns strategically develop their networks.

The primary theme of the collection is to focus upon what they call a Moral Economy, The contrast is with a market economy when transactors meet only as transactors. By contrast, in a small island you never really escape from kinship and friendship. Foster shows how this operates through `managing the exigencies of prepaid phone 
subscriptions in which constant awareness of one's current balance is a practical necessity'. (ibid 8). As Jorgensen's chapter demonstrates, for ordinary users, the presence of phone masts planted in their territory by Digicel provokes all sort of anxieties about surveillance and control. But then local politicians can also claim credit for 'development,' by having such masts installed locally. Companies such as Digicel use advertising to try and appear locally as a friend or ally or to embody to moral virtues of a good citizen, and this may include constant texting directly to consumers, who they reward for their loyalty in the way a friend might. Although as a corporation the actual concern is essential the extraction of revenue.

I tend to characterise the ethnographic approach of anthropologists as 'holistic contextualisation', which is particularly important for understanding smartphones because they don't relate simply to one aspect of our lives, such as politics, or friendship, but to pretty much everything we do and we are. But the term can be misleading if one assumes that holistic merely encompasses the fieldsite; the place where the ethnographer lives and observes. As the volume by Foster and Horst shows, to be truly holistic you have to include everything that impinges upon people even if not directly present, such as the strategies of companies and the regulatory aims of states. This then is the final advantage of anthropology. It is simultaneously extremely parochial, examining in depth very local cultural considerations, but also having to acknowledge and account for the widest possible influences including moral discourses and the political economy.

Costa, E. 2018 Affordances-in-practice: An ethnographic critique of social media logic and context collapse, New Media and Society 20 (10) 3641-3656

Horst, Horst and Miller, Daniel 2016 The Cell Phone: an anthropology of communication Oxford: Berg Ling, Rich 2004. The Mobile Connection: The cell phone's impact on society. San Fransisco: Morgan Kaufamann Publishers

Daniel Miller, Elisabetta Costa, Nell Haynes, Tom McDonald, Razvan Nicolescu, Jolynna Sinanan, Juliano Spyer, Shriram Venkatraman, Xinyuan Wang 2016 How the world changed Social Media, London: UCL Press

The Economist 8/07/2019 How the Pursuit of Leisure Drives Internet Use: movies not grain prices are bringing the poor world online.

Venkatraman, S. 2017 Social Media in South India, London: UCL Press 